\title{
A Gravity Model of Remittance Determinants: \\ Evidence from Latin America and the Caribbean
}

\begin{abstract}
This paper constructs a microeconomic model of the motivation for remittances and uses it to explore the macroeconomic determinants. In addition, a new measure of bilateral remittances is used to estimate a gravity model of remittances for 27 Latin American and Caribbean countries and 18 industrialised countries. The results suggest remittances are motivated by a combination of altruism and self-interest, both of which are encapsulated by economic and non-economic variables.
\end{abstract}

JEL Classification: C23, J61, O11

Keywords: Gravity model, bilateral remittances, Latin America 


\section{INTRODUCTION}

Remittances are the second largest source of net financial flows to developing countries, exceeding external aid and net foreign direct investment in some countries. ${ }^{1}$ The total remittance receipts of US\$588 billion to the Latin American and Caribbean (LAC) countries over the period 1980 to 2010 make it the most important destination of remittances. In 2012 LAC migrants sent US\$64 billion in remittances to their home countries and this is expected to reach US\$84 billion in 2015 (WORLD BANK, 2012). ${ }^{2}$ Mexico features among the top four remittance-receiving countries in the world and for the smaller LAC countries, the share of remittances in GDP is substantial: exceeding 20 percent in Guyana, Haiti and Honduras and 15 percent in El Salvador, Jamaica, Nicaragua and Guatemala (WORLD BANK, 2011)..

[Figure 1]

Given the importance of remittances it is crucial for the governments and the financial sectors in the region to recognize the specificity of each kind of remittance. A systematic analysis of the determinants of remittances would provide invaluable insights to policy makers and contribute to the design of more appropriate regulations. This in turn can promote an effective strategy for the mobilisation of remittances. In this paper the macroeconomic determinants of remittances are estimated for a set of Latin American and Caribbean countries. Generally two approaches to modelling the determinants of remittances have been undertaken in the empirical literature. First a microeconomic approach utilising household survey data (DE LA BRIÈRE, 2002; AMUENDODORANTES and POZO; 2006; YANG, 2008). Second a macroeconomic approach which uses balance of payments data (VARGAS-SILVA and HUANG, 2006; ADAMS, 
2009). A third approach which combines a microeconomic foundation with macroeconomic data has been gaining some momentum (RAPOPORT and DOCQUIER, 2005; SCHIOPU and SIEGFRIED, 2006). It is this latter approach upon which the current study is based.

A panel data set of bilateral remittance flows from 18 industrialised remittance sending countries ${ }^{3}$ to 27 remittance receiving Latin American and Caribbean (LAC) countries $^{4}$ over the period 1998 to 2007 is utilised to study the determinants of remittances. This paper makes several contributions to the literature on remittances. Generally research on remittances in the LAC region is concentrated on a single country or a minority of countries (SAYAN et al., 2010; VARGAS-SILVA and HUANG, 2006; CASTILLO-PONCE et al, 2011). A number of studies have used bilateral data to study remittances (LUETH and RUIZ-ARRANZ, 2008; FRANKEL, 2011; DOCQUIER et al, 2012). These studies feature selected Latin American countries as part of a larger data set that focuses on developing countries in general. In this study a new measure of bilateral remittances is proposed, one that is based on the assumption that aggregate remittance inflows for a country are directly linked to the pattern of a migrating population. This makes it possible to derive bilateral estimates of remittances for a larger group of countries in the LAC region than has been available previously.

Second, the effect on remittances is examined for a comprehensive set of economic, demographic and risk related factors (both man-made and natural). This is unlike earlier studies which tend to ignore the potential effects of demographic and/or risk related factors that may be important in capturing altruistic and investment motivations (VARGAS-SILVA and HUANG, 2006; LIN, 2011). Finally, microeconomic 
theory provides the foundation for exploring the motives for remittances, which are then captured in a model comprising macroeconomic variables. Previous macroeconomic studies of remittances tend to utilise a reduced form equation for remittance with little or no reference to the underlying microeconomic foundations (HIGGINS et al, 2009; FONCHAMYO, 2012; LIM and MORSHED, 2014). These contributions collectively make for a useful and important step in advancing the literature on remittances.

The paper is structured as follows. In section 2 the theoretical model is presented. The linkages between the motives to remit and macroeconomic variables are discussed in section 3. The econometric specification of the gravity model of remittances is presented in Section 4. Section 5 describes how the new measure of bilateral remittances is constructed. Section 6 discusses the results and Section 7 concludes.

\section{THEORETICAL MODEL}

Generally microeconomic models of remittances are based on the motives to remit: altruism and self interest (LUCAS and STARK; 1985). Altruism relates to an individual's desire to improve the income and well being of family members while self-interest remittances are motivated by potential for future benefits. Other microeconomic studies argue that self interest motivated remittances may take the form of reimbursement to relatives back home for the cost migration and/or education abroad (POIRINE, 1997; ILAHI and JAFAREY, 1999). In this case there is an implicit loan agreement between the migrant and relatives back home. Remittances may also be perceived as an insurance or risk diversification device which protects against future uncertainties, (AGARWAL and HOROWITZ, 2002) crises and/or income shocks (YANG and CHOI, 2007). 
In order to explicitly illustrate the altruistic and self interest motives for remittances a simple stylized model is developed similar to that of SCHIOPU and SIEGFRIED (2006) and RAPOPORT and DOCQUIER (2005). The model provides a rigorous justification for some of the a priori relationships discussed later and is the foundation of the macroeconomic model estimated subsequently. There are two periods. A migrant from home country $j$ now living in country $i$ has per-period utility function $u$, which for simplicity is given by $u(x)=\ln x$. The migrant's overall utility depends on their first-period consumption $C_{1}^{i}$, second period consumption $C_{2}^{i}$, and the family's consumption $C_{1}^{j}$ :

$$
u\left(C_{1}^{i}\right)+\beta \mathrm{E}\left[u\left(C_{2}^{i}\right)\right]+\gamma u\left(C_{1}^{j}\right)
$$

where $\beta \in[0,1]$ is the discount factor, $\gamma \in[0,1]$ is the degree of altruism, and $\mathrm{E}\left[u\left(C_{2}^{i}\right)\right]$ is the discounted expected utility from second-period consumption.

In the first period the migrant works in country $i$ and earns income $I^{i}$ which can be allocated to first-period consumption, savings $S$, or remittances to the home country $X^{i j}$. In order for an amount $X^{i j}$ to reach the migrant's family $\tau X^{i j}$ must be spent, where $\tau \geq 1$ represents the cost of remittances. The migrant's family spends all its income $I^{j}$, as well as any remittances it receives, on first-period consumption. Out of savings, the migrant invests an amount $A^{i}$ in a safe hostcountry asset with a return $R^{i}>0$ and an amount $A^{j}$ in a risky home-country asset, which has a return of $R^{j}>0$ with probability $p$ and zero return with probability $1-p$. The migrant's portfolio allocation sub-problem is 
$\max _{A^{i}, A^{j} \geq 0} p u\left(R^{i} A^{i}+R^{j} A^{j}\right)+(1-p) u\left(R^{i} A^{i}\right)$ subject to $A^{i}+A^{j}=S$.

As long as the expected return from the risky asset is higher than from the safe asset, $p R^{i}>R^{j}$, the migrant will invest a positive amount in each asset. Given $S$, the optimal portfolio is

$$
\AA^{b}=\frac{(1-p) R^{j}}{R^{j}-R^{i}} S, \quad \AA^{\dot{b}}=\frac{p R^{j}-R^{i}}{R^{j}-R^{i}} S .
$$

The migrant will invest more in the risky asset the higher is its return, the lower the probability of no return, and the lower the return on the safe asset. Given the optimal asset portfolio, the consumption choice is now

$$
\max _{C_{1}^{i}, X^{i j}, S \geq 0} u\left(C_{1}^{i}\right)+\beta\left[p u\left(p R^{j} S\right)+(1-p) u\left(\frac{(1-p) R^{i} R^{j} S}{R^{j}-R^{i}}\right)\right]+\gamma u\left(C_{1}^{j}\right)
$$

subject to

$$
\begin{aligned}
& C_{1}^{i}+\tau X^{i j}+S=I^{i} \\
& C_{1}^{j}=I^{j}+X^{i j} .
\end{aligned}
$$

As long as the migrant is sufficiently altruistic, the cost of remittances is sufficiently low, or the income differential is high enough, ${ }^{5}$ transfers to the migrant's family are positive and the optimal levels of remittances and investment in the home country asset are

$$
\hat{X}^{i j}=\frac{\gamma I^{i}-(1+\beta) \tau I^{j}}{\tau(1+\beta+\gamma)}, \quad \hat{A}^{j}=\frac{\left(p R^{j}-R^{i}\right)}{R^{j}-R^{i}} \frac{\beta\left(I^{i}+\tau I^{j}\right)}{1+\beta+\gamma} .
$$


Altruism is captured by $\hat{X}^{i j}$, self interest by $\hat{A}^{j}$. By adding the two types of transfers, the following expression is obtained for total remittances $\left(R E M I T_{i j}\right)$ from host country $i$ to home country $j$ :

$$
\operatorname{REMIT}_{i j}=\hat{X}^{i j}+\hat{A}^{j}=\frac{\gamma I^{i}-(1+\beta) \tau I^{j}}{\tau(1+\beta+\gamma)}+\frac{\left(p R^{j}-R^{i}\right)}{R^{j}-R^{i}} \frac{\beta\left(I^{i}+\tau I^{j}\right)}{1+\beta+\gamma}
$$

The migrant's remittances to relatives in the home country depend positively on the migrant's income, and negatively on the family's income. The migrant's remittances for investment depend positively on the migrant's and the family's income and on the interest rate in country $j$, and depends negatively on the interest rate in country $i$. Also, the less risky is the home-country asset (the higher $p$ ) the more is invested in this asset. In general the effect of a change in the migrant's family's income or the cost of remittances is ambiguous. ${ }^{6}$ These comparative static effects are summarized below:

$$
\operatorname{REMIT}_{i j}=f\left(\stackrel{+}{i}\left(^{i}, \stackrel{+/}{I}^{j},{\stackrel{-}{R^{i}}}^{+}, \stackrel{+}{R^{j}}, \stackrel{+}{p}, \stackrel{+-}{\tau}\right)\right.
$$

\section{MICROECONOMIC MOTIVES AND MACROECONOMIC VARIABLES}

This section explains how the microeconomic motives summarized in equation (2) can be captured by macroeconomic variables. Following research by KATSELI and GLYTSOS (1986) and EL-SAKKA and MCNABB (1999) gross domestic product (GDP) in the host and home countries is used to proxy migrant and family income. The returns in home and host country assets may be captured by the home and host countries' deposit or lending interest rates. In the literature this is often captured by the interest rate differential between the home and host countries (FAINI, 1994; EL-SAKKA and MCNABB, 1999). The cost of remitting is difficult to calculate in a macroeconomic study; one way to deal 
with this problem is to use a proxy, for example, the distance between the home and host country (LUETH and RUIZ-ARRANZ, 2008; FRANKEL, 2011).

An examination of the comparative static results obtained in section 2, shows that a higher level of income in the host country stimulates a higher level of remittances while a lower level of income in the home country may attract more or less remittances depending on whether the altruistic of self-interest motive is dominant. Also, a relatively high interest rate in the home country (which reflects the profitability of home-country assets) will motivate self-interest remittances; while greater distances increases the cost of remitting and so reduces remittances.

Altruism and self-interest motives to remit can be captured by macroeconomic variables other than the ones that already appear in equation (2). In order to facilitate this, the model is extended to incorporate additional variables including core gravity model variables, for example the exchange rate and credit availability. An increase in total remittances due to an appreciation in the host country's currency reflects the self-interest motive as migrants seek to benefit from the currency gain whereas a decrease reflects the altruistic motive as a lower level of remittances is needed to support the same standard of living in the home country (AMUEDO-DORANTES et al., 2010; LIN, 2011). Credit availability is an indicator of overall development of a country. If remittances are profitdriven, increased credit availability signals financial deepening in the home country, which attracts self-interest remittances. If remittances are instead influenced by altruism, increased availability of credit at home reduces the need for remittances from abroad (LUETH and RUIZ-ARRANZ, 2008; AREZKI and BRÜCKNER, 2011). ${ }^{7}$ 
In our model, self-interest is captured through remittances for investment. A second type of self interest indentified in the literature is the inheritance motive. At the macro level, the inheritance motive may be captured by the difference in the level of skills between the home and host countries and the family size. This is because the high skilled migrants may have less intention to return home and hence reduces the desire to add to family assets in order to buy into future returns. (BOLLARD et al, 2011). Another variable that captures the inheritance motive is the relative dependency ratio. A positive sign indicates that that the dominant motive is altruism as higher number of dependents in the home country (relative to the host country) stimulates foreign financial support (ARVIN and LEW, 2012; FONCHAMYO, 2012). A negative sign means in the presence of higher home country dependency ratio, remittances is falling; one way of rationalising this behaviour is that higher dependency ratios have a dampening effect on the inheritance motive and hence discourage remittances.

Finally the insurance hypothesis can be tested by including risk variables. A positive effect sign is consistent with the insurance hypothesis as migrants seek to complement the income of relatives back home in challenging economic times, while an inverse relationship is indicative of the more general self-interest motivated as investors flee the country (AGARWAL and HOROWITZ, 2002).

\section{MODEL SPECIFICATION}

Given the discussion in the section above the model for remittances can now be written in the following form: 


$$
\begin{aligned}
& R_{E M I T}^{t}=\beta_{0}+\beta_{1} G D P_{i}^{t}+\beta_{2} G D P_{j}^{t}+\beta_{3} D G D P P C_{i j}^{t} \\
& +\beta_{4} D_{I S T}+\beta_{5} D_{i N} T_{j i}^{t}+\beta_{6} R_{E R}^{t}+\beta_{7} R_{i} R_{j}^{t}+\beta_{8} C R E D I T_{i}^{t}+\beta_{9} C_{R E D I T}^{t} \\
& +\beta_{10} D_{S K I L L}^{t}+\beta_{11} D_{D E P E N D}^{t}+\beta_{12}\left(\text { DSKILL }_{i j}^{t} \times D D_{\text {DPEND }}^{t}{ }_{j i}\right) \\
& +\beta_{13} D_{I S A S T E R}^{t}+\beta_{4} R_{S S K_{j}^{t}}+\beta_{5} A D J_{i j}+\beta_{6} L A N G_{i j}+\beta_{7} C O L_{i j} \\
& +\theta^{t}+\varepsilon
\end{aligned}
$$

$R E M I T_{i j}^{t}$ is a measure of bilateral remittance flows from country $i$ to country $j$

(discussed in Section 5). The intercept is denoted $\beta_{0}$, the time specific effects, $\theta^{t}$ and $\varepsilon_{i j}^{t}$

is the error term. All variables are estimated in natural logarithms except for the dummies and the dependency ratio. A definition of the variables and data sources is provided in the Appendix.

The model includes the economic size of both countries $\left(G D P_{i}^{t}\right.$ and $G D P_{j}^{t}$ respectively); in line with the gravity model a variable to represent the absolute difference in GDP per capita income levels $\left(D G D P P C_{i j}^{t}=\left|\ln G D P P C_{i}^{t}-\ln G D P P C_{j}^{t}\right|\right)$ is also included. A positive coefficient means that greater disparities between countries' development levels stimulate remittances and reinforces the altruistic motive, whereas a negative relationship reinforces the self-interest motivation for remitting (SCHIOPU and SIEGFRIED, 2006).

Three sets of variables capturing altruistic and self-interest motives of remittances are included. The first set represents economic conditions and includes the real interest rate differential, $D I N T_{j i}^{t}=\left(\ln I N T_{j}^{t}-\ln I N T_{i}^{t}\right)$, the real exchange rates for both countries $\left(R E R_{i}^{t}\right.$ and $R E R_{j}^{t}$ ) as well as private sector credit as a share of GDP ( $C R E D I T_{i}^{t}$ and $\left.C R E D I T_{j}^{t}\right)$ 
Demographics comprise a further set of variables: the relative skills level, $\operatorname{DSKILL}_{i j}^{t}=\left(\ln S K I L L_{i}^{t}-\ln S K I L L_{j}^{t}\right) ;$ the relative age dependency ratio, $D D E P E N D_{j i}^{t}=\left(D E P E N D_{j}^{t}-D E P E N D_{i}^{t}\right)$ and an interaction term, $\left(\right.$ DSKILL $\left._{i j}^{t} \times D D E P E N D_{j i}^{t}\right)$. The last term accounts for the possibility that migrants remit more when the sending country has a higher skills base and a lower age dependency ratio.

Third a set of risk-related variables is also included. Natural disasters ( DISASTER ${ }_{j}^{t}$ ) refer to 11 separate dummies for biological disasters, climatic disasters, geophysical disasters, and other large scale disasters. The international risk perception index, $R I S K_{j}^{t}$, is a composite index comprising 12 indicators of political risk.

The last group of variables is comprised of three dummy variables in a manner similar to LUETH and RUIZ-ARRANZ, (2008). These are intended to capture the ties between two countries. The greater are these ties the greater is the probability that an individual will migrate to this country than other potential host country. In the case of Latin America, being adjacent $\left(A D J_{i j}\right)$ to the Mexican border is likely to increase remittances because travel costs are lower; movement from one country to another can take place more quickly and with less difficulty and the propensity for unofficial cross border money transfers increases. Second, a common language ( $\left.L A N G_{i j}\right)$ is expected to enhance remittances - migrants who speak the same language will secure employment more easily. Finally, a shared history of colonial ties $\left(C O L_{i j}\right)$ may mean that the coloniser has contributed to the state of the institutions of the colonised. It may be easier for citizens of the colony to travel to the coloniser or there may be political ties. The 
summary statistics for all variables are shown in Table 1. A correlation matrix of the independent variables is shown in Table 2.

[Tables 1 and 2]

\section{MEASUREMENT OF BILATERAL REMITTANCES}

Bilateral data on remittances are, in general, not available. On the assumption that the patterns of remittances received by the LAC countries are linked to the patterns of LAC migrant population outflows to the industrialised countries, a measure of bilateral remittances can be calculated. Let $R_{i j}$ represent the level of remittance flows from country $i$ (for $i=1,2, \ldots, \mathrm{n}$ ) to country $j$. It follows that the total level of remittances to country $j$ can be written as the sum of the individual remittances from all countries:

$$
\sum_{i=1}^{n} R_{i j}=R_{1 j}+R_{2 j}+\ldots+R_{n j}
$$

Rewriting equation (4) in shares gives:

$$
\frac{R_{1 j}}{\sum_{i=1}^{n} R_{i j}}+\frac{R_{2 j}}{\sum_{i=1}^{n} R_{i j}}+\ldots+\frac{R_{n j}}{\sum_{i=1}^{n} R_{i j}}=1
$$

where each term on the left hand side (LHS) of equation (5) is the proportion of remittances received by country $j$ that originates in country $i$.

Similarly, let $M_{j i}$ be the level of migrant population flows from country $j$ to country $i$ (for $i=1,2, \ldots, \mathrm{n}$ ), hence the total migrant population flows from country $j$ can be represented as the sum of migrant flows from country $j$ to all other countries: 


$$
\sum_{i=1}^{n} M_{j i}=M_{j 1}+M_{j 2}+\ldots+M_{j n}
$$

Rewriting equation (6) in terms of shares gives:

$$
\frac{M_{j 1}}{\sum_{i=1}^{n} M_{j i}}+\frac{M_{j 2}}{\sum_{i=1}^{n} M_{j i}}+\ldots+\frac{M_{j n}}{\sum_{i=1}^{n} M_{j i}}=1
$$

where each LHS term in equation (7) is the proportion of migrants in country $i$ that originates from country $j$.

Assuming that the share of bilateral remittance flows from country $i$ to country $j$ is equivalent to the share of migrant population flows from country $j$ to country $i$ gives:

$$
\frac{R_{i j}}{\sum_{i=1}^{n} R_{i j}}=\frac{M_{j i}}{\sum_{i=1}^{n} M_{j i}}
$$

From this, a measure of bilateral remittance flows from country $i$ to country $j$ can be calculated as the product of the total remittances received by country $j$ and the share of migrant population flows from country $j$ to country $i$ :

$$
R_{i j}=\sum_{i=1}^{n} R_{i j} \times \frac{M_{j i}}{\sum_{i=1}^{n} M_{j i}}
$$

HARRISON et al. (2004) also assume a direct link between the patterns of migrating populations to a foreign country and remittances sent back to the home country. This assumption has two main caveats. First, not all people working in a foreign country are migrants. Second, remittances to the home country may be sent by people other than migrants in the foreign country. Nevertheless, HARRISON et al. (2004) suggest the existence of a direct migration remittance link on the grounds that remittances 
tend to be sent by migrants abroad who send their earnings back to the country from which they have migrated.

One way of exploring the validity of the assumption that the share of remittances to country $j$ from country $i$ is equivalent to the share of migrants from country $j$ to country $i$ is to look at bilateral data published by the Bank of Mexico. The correlation between the estimated remittances and official estimates of workers' remittances from the US to Mexico (annualised monthly values) exceeds 0.95 (see Table 3), thus supporting the assumed remittance-migration approach. ${ }^{8}$

[Table 3]

\section{EMPIRICAL RESULTS}

Table 4 presents the results from estimating variations of equation (3). The baseline model in column (1) shows the relationship between remittances and the core gravity variables. Country fixed effects for the sending and receiving countries are interacted with the time fixed effects and added to the pooled least squares regression to account for unobservable time varying variables across individual countries. Ramsey's RESET test (RAMSEY 1969), while primarily used to test for functional form misspecification, can also be used to check whether the relationship between remittances and the explanatory variables is non-linear. The result reveals that the model in column (1) has omitted nonlinear variables. Because the specific nature of the omitted non-linear variables is unknown the model is re-estimated. In column (2) unobservable time varying fixed effects are replaced with time varying economic and demographic variables; risk factors are added in column (3). Following this, an LM test is performed to check for the joint significance of non-linear explanatory variables. ${ }^{9}$ In both cases the null hypothesis that 
the coefficients are jointly equal to zero cannot be rejected and on this basis the models in their current form are accepted. The RE estimator is the preferred choice of estimator for these models given the results of both the Breusch-Pagan Lagrange Multiplier (LM) statistic and the HAUSMAN (1978) test.

GDP in both countries matters for remittances; countries with higher income send and receive larger volumes of remitted earnings. The positive coefficient on GDP in the home country is consistent with the investment motive for remittances. In contrast, the impact of the GDP per capita differential variable provides support for the altruistic motive. The distance elasticity is negative and significant, indicating that a higher cost of remitting reduces the volume of remittances.

The enhancing effect on remittances of the Mexican border is significant across all specifications. Up to one million people cross the border legally as part of a day's work and bring back economic benefits from US employment. Sharing a common language is also significant, while remittances to the LAC countries are unresponsive to colonial ties. This result conflicts with the findings of LUETH and RUIZ-ARRANZ (2008) who suggest that a colonial history is important because of the existence of preferential visa arrangements between the 'mother' countries and their former colonies. Such visa arrangements play a more limited role for the LAC countries, perhaps leading to more illegal migration. To a certain extent, the effect of a shared colonial history is captured by the language dummy (the correlation between the two dummies is 0.60 ), which is not surprising because a myriad of languages spoken in the advanced countries Dutch, English, French, Spanish, and Portuguese - were transmitted abroad via colonial links and adopted in the LAC countries. 
The real interest rate differential is significant at the 10 percent level in the full model specification and insignificant otherwise. In combination with the per capita income differential, these results suggest remittances are driven more by altruism than by self-interest. The real exchange rates are in significant in all models, while credit availability is a significant in the full model specification (column (3)). Credit availability in both the home and foreign countries is equally important for the investment motive of remittances.

In terms of the demographic factors, both the skilled labour and dependency ratio differentials are statistically significant. Although the interaction term does not discriminate clearly between the motives to remit, its negative and significant coefficient suggests individuals, in an attempt to boost their potential earnings, migrate to countries with a relatively higher skills level accompanying a relatively lower age dependency ratio.

Latin America has long been affected by natural disasters but remittances are sensitive to certain types only. Flooding (column 3), mass movements of water, and epidemics generate a favourable response from abroad. An exception to the altruistic nature of migrants, however, is the presence of extreme temperatures. ${ }^{10}$ Remittances from abroad tend to increase in times of political uncertainty; the positive and significant coefficient for political risk in the home country suggests the selfless motives of altruism and insurance prevail over the self-interest motive of investment. A more mixed picture emerges when the composite index for political risk is disaggregated into its subcomponents. ${ }^{11}$ Remittances increase during times of external conflict and military involvement in politics. In contrast, ethnic tensions reduce the volume of remittances, 
reflecting either affordability issues which prevent the hedging of risks via a migration strategy or the withholding of profit driven remittances.

Robustness checks are carried out on the preferred model specification (column 3, Table 4). First, four regional dummies (North America, Europe, Asia, and Oceania) are added to control for regional differences among the host countries. Along similar lines, YANG (2008) uses region-specific year effects to allow for time-varying factors common to all countries in the same region. As shown in column (1) of Table 5, three dummies are insignificant (Oceania is dropped because of multicollinearity), implying heterogeneity across regions is not a major issue. Second, as Mexico is by far the largest recipient of remittances among the LAC countries, the sensitivity of the results to its exclusion is investigated. As shown in column (2), the results are largely unaffected.

[Figure 2]

The results may suffer from endogeneity bias arising from the simultaneous determination of remittances and the explanatory variables. One way of dealing with the endogeneity problem is to use instrumental variable (IV) techniques. For example, ADAMS (2009) uses distance and language to instrument for the skill level of migrants while HIGGINS et al (2004) uses the terms of trade to instrument for the real exchange rate. Other variables used as instruments include child characteristics (DE SOUZA and DUVAL, 2010), latitude, distance between origin and destination countries (BUGAMELLI and PATERNO, 2009), and geographic, political and cultural indicators (FRENKEL, 2010). Most of these variables have been explicitly incorporated in the model because they are expected to have a direct impact on remittances, while information for other variables, for example child characteristics, is not available. 
Another common instrument is to use lagged regressors (AMUENDODORANTES et al., 2010; AREZKI and BRÜCKNER, 2011; LIN, 2011). This is broadly the approach taken in this paper. First, the time-varying explanatory variables in equation (3) are lagged by one year. The results are shown in column (3) of Table 5. Second, in column (4) each variable (excluding dummy variables, natural disaster and distance) is instrumented by its lagged counterpart since these are orthogonal to the error and estimated using panel data two stage least squares (TSLS). The latitude of a country is also used as an additional instrumental variable (BUGAMELLI and PATERNO, 2009). The first-stage F statistic of excluded instruments on all first-stage regressions are in excess of 10 (the rule of thumb threshold recommended by Stock and Staiger (STAIGER and STOCK; 1997) to avoid concerns pertaining to weak instruments). ${ }^{12}$ The AndersonRubin Wald F test tests the null hypothesis that the coefficients of the endogenous regressors in the structural equation are jointly equal to zero. The null is rejected. A further test of the relevancy of instruments, the Anderson canonical correlations test, rejects the null hypothesis so the instruments are deemed relevant. Since an additional instrument is included, the Sargan test for over-identified restrictions is applied. The null hypothesis, that the instruments are exogenous, cannot be rejected. On the basis of these diagnostics, the instruments are valid and the results in column 4 are accepted.

Based on the results in columns (3) and (4) the core gravity variables remain significant, the coefficients for credit availability, the interaction term and political risk lose significance. The insignificant credit coefficients weaken the investment hypothesis. The insignificant interaction term suggests only the direct effects of skilled labour and the dependency ratio matter for remittances. The loss of significance for political risk 
suggests altruism is a short-term phenomenon, prevailing in the current year only and not the previous year. That is, altruistic remitters behave in a strategic manner: remitting transfers during times of political uncertainty but saving transfers when political tensions subside.

[Table 5]

\section{CONCLUSION}

This paper has developed a new measure of bilateral remittances to estimate the determinants of bilateral remittances from 18 industrialised countries to 27 LAC countries over the period 1998 to 2007 within a gravity model framework. The results suggest remittances to the LAC countries are motivated by both altruism and self-interest. Evidence in support of the former is indicated by the GDP per capita differential, the dependency ratio, several types of natural disasters and several types of political risks. Evidence in support of the latter is provided by the availability of credit and certain types of natural disasters and political risks. The core gravity variables and the demographic factors also contribute to the explanation of remittances to the LAC countries. Robustness tests, however, indicate a weakening of the respective motives over time.

The results have several important policy implications. First, the negative coefficient on the distance variable (which is a proxy for the cost of remittances) suggests a twin policy of lower transaction costs and greater financial development in the LAC countries is necessary to foster remittances through formal channels. A similar conclusion had been arrived at in earlier research (ADAMS; 2009; PIRACHA and SARAGOI, 2012). Reducing the cost of remitting increases a migrant's disposable income and possibly investment in the home country. Remitters and recipients need to have access to 
financial services such as savings instruments since a weak financial infrastructure impedes the transfer of remittances (through formal channels) and restricts the potential of remittances to spur development through investment. If remittances are to have a role beyond small business ventures, financial development is essential.

Second, the differing results for the contemporaneous and lagged effects of political risk suggest migrant altruism might not endure over time. At some point there will be a levelling off and possibly a decline in remittances. This result should be of concern to those policy makers who see remittances as a stable source of revenue into the future. Economic strategies that focus on diversification are crucial for sustained economic development.

Finally, the finite nature of future remittance inflows highlights the urgency of channelling remittances into their most productive uses; more needs to be done by both financial institutions and governments in order to maximise the development impact of remittances. 


\section{REFERENCES}

ADAMS R. H. (2009) The determinants of international remittances in developing countries, World Development 37, 93-103.

AGARWAL R. and HOROWITZ A. W. (2002) Are international remittances altruism or insurance? Evidence from Guyana using multiple-migrant households, World Development 30, 2033-44.

AMUEDO-DORANTES C., POZO S. and VARGAS-SILVA C. (2010) Remittances in small island developing states, Journal of Development Studies 46, 941-60.

AREZKI R. and BRÜCKNER M. (2011) Rainfall, financial development, and remittances: Evidence from Sub-Saharan Africa, Working Paper No. WP/11/153, International Monetary Fund (IMF), Washington DC.

ARVIN B. and LEW B. 2012 Do happiness and foreign aid affect bilateral migrant remittances? Journal of Economic Studies, 39. 2, 212-230.

Bank of Mexico, 2012, Available at http://www.banxico.org.mx/SieInternet/consultarDirectorioInternetAction.do?accion=con sultarCuadro\&id,Cuadro=CE81\&sector $=1 \&$ locale=en, Mexico.

BOLLARD A., MCKENZIE D., MORTEN M. and RAPAPORT, H. (2011) Remittances and the brain drain revisited: The micro-data show that more educated migrants remit more, World Bank Economic Review 25, 1, 132-156.

BREUSCH T. and PAGAN A. (1980) The Lagrange multiplier test and its applications to model specification in econometrics, Review of Economic Studies 47, 239-53.

BUGAMELLI M. and PATERNO F. (2009) Output growth volatility and remittances, Economica 78, 480-500.

CASTILLO-PONCE R. A., TORRES-PRECIADO V. H., and MANZANARESRIVERA J. L (2011) Macroeconomic determinants of remittances for a dollarized economy: the case of El Salvador, Journal of Economic Studies 38, 562-76.

Centre d'etudes prospectives et d'informations internationales (CEPII), 2011, Available at http://www.cepii.fr/anglaisgraph/bdd/distances.htm, Paris.

DE P. K. and RATHA D. (2012) Impact of remittances on household income, asset and human capital: Evidence from Sri Lanka, Migration and Development 1, 163-179. 
DE LA BRIÈRE B., SADOULET A., DE JANVRY A. and LAMBERT S. (2002) The roles of destination, gender, and household composition in explaining remittances: An analysis for the Dominican Sierra, Journal of Development Economics 68, 309-28.

DE SOUZA J. and DUVAL L. (2010) Geographic distance and remittances in Romania: Out of sight, out of mind? International Economics, 121, 81-98.

EL-SAKKA M. I. T. and MCNABB, R. (1999) The macroeconomic determinants of emigrant remittances, World Development 27, 1493-1502.

Emergency Events Database (EM-DAT), 2011, Available at http://www.emdat.be, Brussels.

FAINI, R. (1994) Workers remittances and the real exchange rate: A quantitative framework, Journal of Population of Economics, 7, 235-45.

FONCHAMYO D.C. (2012) The Altruistic Motive of Remittances: A Panel Data Analysis of Economies in Sub Saharan Africa, International Journal of Economics and Finance; 4, 10, 192-200.

FRANKEL J. A. (2011) Are bilateral remittances countercyclical? Open Economies Review 22, 1-16.

GLYTSOS N. P. (2002) A model of remittance determination applied to Middle East and North Africa countries, Discussion Paper No. 73, Centre of Planning and Economic Research (KEPE), Athens.

HARRISON A., BRITTON T. and SWANSON A. (2004) Working abroad - the benefits flowing from nationals working in other economies, OECD Round Table on Sustainable Development, Paris.

HAUSMAN J. A. (1978) Specification tests in econometrics, Econometrica 46, 1251-71.

HIGGINS M. L., HYSENBEGASI A. and POZO S. (2004) Exchange-rate uncertainty and workers' remittances, Applied Financial Economics 14, 403-11.

International Country Risk Guide (ICRG), 2010, Available at http://www.prsgroup.com/icrg.aspx. New York.

ILAHI N. and JAFAREY S. (1999) Guest worker migration, remittances and the extended family: Evidence from Pakistan. Journal of Development Economics 58, 485512.

International Monetary Fund (IMF), 2006, Two current issues facing developing countries, World Economic Outlook, Chapter II, Washington, DC. 
International Monetary Fund (2011), International Financial Statistics (IFS), ESDS International, University of Manchester.

KATSELI L. and GLYTSOS N. (1986) Theoretical and Empirical Determinants of International Labour Mobility: A Greek-German Perspective, Centre for Economic Policy Research Working Paper 148.

LIM S. and MORCHED, M. (2014) International migration, migrant stock and remittances: re-examining the motives to remit, Quarterly Journal of Economics and Finance. Available at: http://dx.doi.org/10.1016/j.qref.2014.10.001.

LIN H. L. (2011) Determinants of remittances: Evidence from Tonga, Working Paper No. WP/11/18, International Monetary Fund (IMF), Washington DC.

LUCAS R. E. B. and STARK O. (1985) Motivations to remit: Evidence from Botswana, Journal of Political Economy 93, 901-18.

LUETH E. and RUIZ-ARRANZ M. (2008) Determinants of bilateral remittance flows, Journal of Macroeconomics, 8, 1-21.

Organisation for Economic Co-operation and Development (OECD), 2009, International Migration Statistics (IMS), ESDS International, University of Manchester.

PIRACHA M. and SARAGOI A. (2012) The Determinants of Remittances: Evidence from Moldova, Oxford Development Studies, 40, 4, 467-491.

POIRINE B. (1997) A theory of remittances as an implicit family loan arrangement, World Development 25, 589-611.

RAMSEY J. B. (1969) Tests for specification errors in classical linear least-squares regression analysis, Journal of the Royal Statistical Society 31, 350-71.

RAPOPORT H. and DOCQUIER F. (2005) The economics of migrants' remittances, Discussion Paper No. 1531, Institute for the Study of Labour (IZA), Bonn.

SAYAN S., TAŞ B. O. and YALTA Y. (2010) Cyclical behaviour of Mexican remittances over the Mexican and the US business cycles, Working Paper No. 8, TOBB University of Economics and Technology, Ankara.

SCHIOPU I. and SIEGFRIED N. (2006) Determinants of workers' remittances: Evidence from the European neighbouring region, Working Paper Series No. 688, European Central Bank (ECB), Frankfurt.

STAIGER D. and STOCK J. H. (1997): Instrumental Variables Regression with Weak Instruments, Econometrica, 65, 3, 557-586. 
VARGAS-SILVA C. and HUANG P. (2006) Macroeconomic determinants of workers' remittances: Host versus home country's economic conditions, The Journal of International Trade and Economic Development 15, 81-99.

WHITE H. (1980) A heteroskedasticity-consistent covariance matrix estimator and a direct test for heteroskedasticity, Econometrica 48, 817-38.

World Bank (WB), 2011, World Development Indicators (WDI), ESDS International, University of Manchester.

World Bank (WB), 2012, Migration and Development Brief 19, Available at: http://siteresources.worldbank.org/INTPROSPECTS/Resources/3349341288990760745/MigrationDevelopmentBrief19.pdf, Washington DC.

YANG D. and CHOI H. J. (2007) Are remittances insurance? Evidence from rainfall shocks in the Philippines, World Bank Economic Review 21, 219-48.

YANG D. (2008) International migration, remittances and household investment: evidence from Philippine migrants' exchange rate shocks, The Economic Journal, 118, 591-630. 


\section{APPENDIX: DESCRIPTION OF DATA}

- Remittances are workers' remittances and compensation of employees, in current US dollars (World Development Indicators (WDI)). Remittances comprise transfers by migrant workers and wages and salaries earned by non-resident workers. Remittances are deflated by US consumer prices $(2000=100)$, taken from International Financial Statistics (IFS). Data on the inflows of foreign populations by nationality are from International Migration Statistics (IMS). The bilateral migration data refer to LAC migrant population inflows to the OECD countries; data for LAC migrant population outflows to the OECD countries are not available.

- GDP for both countries (constant 2000 US dollars) are taken from WDI.

- Distance, available from the CEPII, is the great circle distance measured in kilometres between the economic centres of the two countries.

- GDP per capita (constant 2000 US dollars), sourced from WDI, is the absolute difference between the two countries' per capita GDP levels.

- Adjacency, from the CEPII, is a zero-one dummy denoting adjacent borders.

- Language, from the CEPII, is a dummy for a shared official language.

- Colony, from the CEPII, is a dummy for colonial links between two countries.

- The real interest rate is the deposit rate adjusted for inflation, taken from WDI.

- Exchange rate for both countries is the official exchange rate in local currency units per US dollar, sourced from WDI.

- Credit for both countries refers to private sector credit as a share of GDP, from WDI.

- Skilled labour refers to the enrolment rates in tertiary education, taken from WDI. 
- Dependency ratio is the number of dependents (aged under 15 and above 65) as a ratio of the working age population (aged between 15 and 64), sourced from WDI.

- Natural disasters refer to 11 separate dummies for biological disasters (epidemics and insect infestations), climatic disasters (droughts, extreme temperatures and wildfires), geophysical disasters (earthquakes, volcanoes and mass movements of earth) and other large scale disasters (storms, flooding and mass movements of water), all of which are constructed using information made available by EM-DAT.

- Risk refers to the international perception of a country's political risk rating, obtained from the International and Country Risk Guide (ICRG). This is a composite index comprising 12 indicators of political risk. 
Table 1 Summary Statistics

\begin{tabular}{lccccc}
\hline \hline Variable & Mean & $\begin{array}{c}\text { Standard } \\
\text { deviation }\end{array}$ & Minimum & Maximum & No. of obs \\
\hline Remittances & 16.63 & 2.43 & 5.12 & 23.77 & 1344 \\
Host country GDP & 27.02 & 1.32 & 24.58 & 30.07 & 4860 \\
Home country GDP & 23.11 & 2.18 & 19.34 & 27.42 & 4860 \\
Distance & 9.11 & 0.38 & 7.74 & 9.88 & 4860 \\
GDP per capita differential & 2.12 & 0.81 & 0.17 & 4.69 & 4860 \\
Adjacency & $0.21 \times 10^{-2}$ & 0.04 & 0.00 & 1.00 & 4860 \\
$\begin{array}{l}\text { Language } \\
\text { Colony }\end{array}$ & 0.12 & 0.33 & 0.00 & 1.00 & 4860 \\
$\begin{array}{l}\text { Real interest rate differential } \\
\text { Host country }\end{array}$ & 0.05 & 0.23 & 0.00 & 1.00 & 4860 \\
$\quad$ real exchange rate & 1.04 & 1.11 & -6.24 & 6.52 & 3377 \\
$\begin{array}{l}\text { Home country } \\
\text { real exchange rate }\end{array}$ & 5.59 & 1.95 & 3.90 & 11.83 & 4860 \\
$\begin{array}{l}\text { Host country } \\
\text { private sector credit }\end{array}$ & 7.20 & 2.36 & 4.19 & 14.62 & 4716 \\
$\begin{array}{l}\text { Home country } \\
\text { private sector credit }\end{array}$ & 3.72 & 0.38 & 3.53 & 5.44 & 4671 \\
$\begin{array}{l}\text { Skills differential } \\
\begin{array}{l}\text { Dependency ratio } \\
\quad \text { differential }\end{array}\end{array}$ & 0.97 & 0.60 & -0.46 & 3.67 & 2048 \\
$\begin{array}{l}\text { Dependency ratio differential } \\
\quad \text { Skills differential }\end{array}$ & 15.48 & 19.98 & -5.84 & 118.16 & 2048 \\
$\begin{array}{l}\text { Flooding } \\
\text { Political risk }\end{array}$ & 0.50 & 0.50 & 0.00 & 1.00 & 4860 \\
\hline & 64.80 & 8.58 & 38.00 & 82.50 & 3960 \\
\hline
\end{tabular}


Table 2 Correlation Matrix

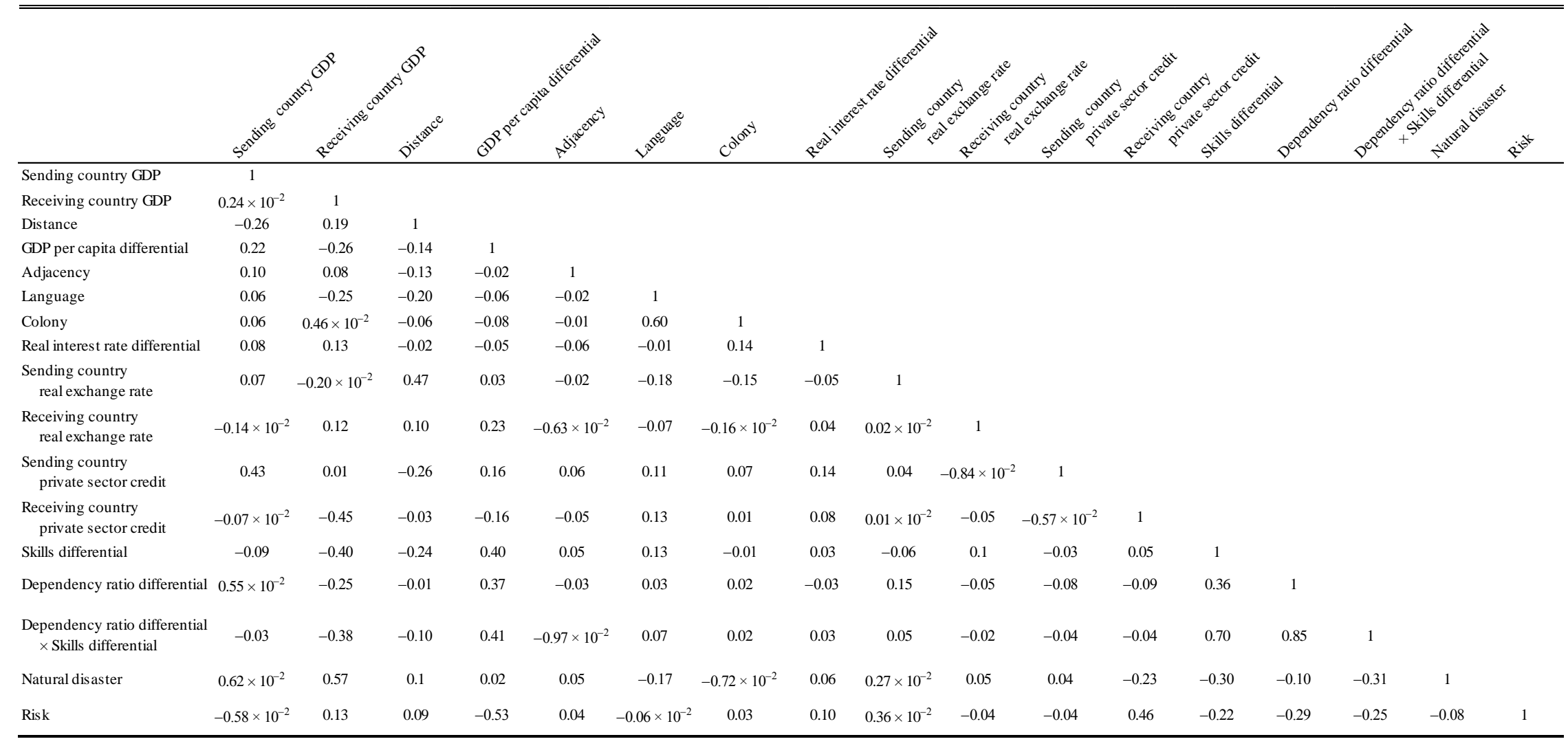


Table 3 A Comparison of Bilateral Remittances from the US to Mexico (US\$ million)

\begin{tabular}{ccc} 
Year & Estimated data & Official data $^{\mathrm{a}}$ \\
\hline 1998 & 6.68 & 5.63 \\
1999 & 6.68 & 5.91 \\
2000 & 7.25 & 6.57 \\
2001 & 9.55 & 8.90 \\
2002 & 10.20 & 9.81 \\
2003 & 14.60 & 15.14 \\
2004 & 17.20 & 18.33 \\
2005 & 18.80 & 21.69 \\
2006 & 21.20 & 25.57 \\
2007 & 20.50 & 26.06 \\
\hline
\end{tabular}

${ }^{\mathrm{a}}$ Source: Bank of Mexico. 
Table 4 Model of OECD-LAC Remittance Flow Determinants ${ }^{\mathrm{a}}$

\begin{tabular}{|c|c|c|c|c|}
\hline Regressors & $(1)$ & $(2)$ & (3) & Expected sign \\
\hline Host country GDP & $\begin{array}{c}0.36^{* * * *} \\
(2.78)\end{array}$ & $\begin{array}{c}0.82 * * * \\
(6.45)\end{array}$ & $\begin{array}{c}0.83 * * \\
(6.47)\end{array}$ & $(+)$ \\
\hline Home country GDP & $\begin{array}{c}0.44 * * \\
(3.62)\end{array}$ & $\begin{array}{c}1.05^{* *} \\
(6.73)\end{array}$ & $\begin{array}{c}1.16^{* *} \\
(8.49)\end{array}$ & $(+)$ \\
\hline Distance & $\begin{array}{c}-2.43 * * \\
(-15.90)\end{array}$ & $\begin{array}{c}-1.46^{* *} \\
(-3.53)\end{array}$ & $\begin{array}{c}-1.38 * * \\
(-3.48)\end{array}$ & $(-)$ \\
\hline GDP per capita differential & $\begin{array}{l}0.36 \\
(1.28)\end{array}$ & $\begin{array}{c}1.15^{* *} \\
(3.98)\end{array}$ & $\begin{array}{c}1.42 * * \\
(4.84)\end{array}$ & $\begin{array}{c}\text { altruism (+) } \\
\text { investment (-) }\end{array}$ \\
\hline Adjacency & $\begin{array}{c}2.22 * * \\
(14.71)\end{array}$ & $\begin{array}{c}2.24 * * \\
(4.55)\end{array}$ & $\begin{array}{c}1.97 * * \\
(4.18)\end{array}$ & $(+)$ \\
\hline Language & $\begin{array}{l}1.42 * * \\
(9.07)\end{array}$ & $\begin{array}{c}1.86^{* *} \\
(2.48)\end{array}$ & $\begin{array}{c}2.68 * * \\
(4.55)\end{array}$ & $(+)$ \\
\hline Colony & $\begin{array}{l}0.11 \\
(0.74)\end{array}$ & $\begin{array}{l}0.46 \\
(0.61)\end{array}$ & $\begin{array}{l}-0.23 \\
(-0.33)\end{array}$ & $(+)$ \\
\hline Real interest rate differential & - & $\begin{array}{l}0.06 \\
(1.15)\end{array}$ & $\begin{array}{c}0.08 * \\
(1.69)\end{array}$ & investment $(+)$ \\
\hline Host country real exchange rate & - & $\begin{array}{l}-0.10 \\
(-0.85)\end{array}$ & $\begin{array}{l}-0.13 \\
(-1.12)\end{array}$ & $\begin{array}{c}\text { altruism (+) } \\
\text { investment (-) }\end{array}$ \\
\hline Home country real exchange rate & - & $\begin{array}{l}0.06 \\
(1.07)\end{array}$ & $\begin{array}{r}0.09 \\
(1.57)\end{array}$ & $\begin{array}{c}\text { altruism }(-) \\
\text { investment }(+)\end{array}$ \\
\hline Host country private sector credit & - & $\begin{array}{c}-0.45^{* *} \\
(-2.60)\end{array}$ & $\begin{array}{c}-0.43 * * \\
(-2.65)\end{array}$ & $\begin{array}{c}\text { altruism (+) } \\
\text { investment (-) }\end{array}$ \\
\hline Home country private sector credit & - & $\begin{array}{c}0.58 * * \\
(2.57)\end{array}$ & $\begin{array}{c}0.49 * * \\
(2.39)\end{array}$ & $\begin{array}{c}\text { altruism }(-) \\
\text { investment }(+)\end{array}$ \\
\hline Skills differential & - & $\begin{array}{l}1.34 * * \\
(3.54)\end{array}$ & $\begin{array}{c}1.35 * * \\
(3.56)\end{array}$ & $\begin{array}{c}\text { altruism }(+) \\
\text { investment }(+)\end{array}$ \\
\hline Dependency ratio differential & - & $\begin{array}{c}0.15^{* *} \\
(4.77)\end{array}$ & $\begin{array}{c}0.16^{* *} \\
(4.74)\end{array}$ & altruism (+) \\
\hline $\begin{array}{l}\text { Dependency ratio differential } \\
\times \text { Skills differential }\end{array}$ & - & $\begin{array}{c}-0.07 * * \\
(-3.49)\end{array}$ & $\begin{array}{c}-0.06 * * \\
(-3.16)\end{array}$ & $\begin{array}{c}\text { altruism (-) } \\
\text { investment (-) }\end{array}$ \\
\hline Natural disaster & - & - & $\begin{array}{c}0.29 * * \\
(2.33)\end{array}$ & $\begin{array}{c}\text { altruism (+) } \\
\text { investment (-) }\end{array}$ \\
\hline Political risk & - & - & $\begin{array}{c}0.02 * * \\
(2.56)\end{array}$ & $\begin{array}{c}\text { altruism (+) } \\
\text { investment (-) }\end{array}$ \\
\hline Intercept & $\begin{array}{c}15.94 * * \\
(4.13)\end{array}$ & $\begin{array}{c}-24.27 * * \\
(-2.98)\end{array}$ & $\begin{array}{c}-30.12 * * \\
(-3.82)\end{array}$ & - \\
\hline No. of obs & 1344 & 363 & 353 & - \\
\hline No. of groups & - & 110 & 106 & - \\
\hline $\mathrm{R}^{2}$ & 0.919 & 0.724 & 0.775 & - \\
\hline RMSE & 0.826 & - & - & - \\
\hline RESET $^{\mathrm{b}}$ & $7.60 * *$ & - & - & - \\
\hline LM test ${ }^{\mathrm{c}}$ & - & $251.37 * *$ & $240.08^{* *}$ & - \\
\hline Hausman $^{\mathrm{d}}$ & - & 7.10 & 12.82 & - \\
\hline LM test ${ }^{\mathrm{e}}$ (chi-squared(2)) & & $\begin{array}{c}1.09 \\
(0.5812)\end{array}$ & $\begin{array}{c}4.05 \\
(0.1302)\end{array}$ & \\
\hline Time & $3.39 * *$ & $110.20 * *$ & $116.91 * *$ & - \\
\hline Time $\times$ Host country & $8.02 * *$ & - & - & - \\
\hline Time $\times$ Home country & $2182.74 * *$ & - & - & - \\
\hline
\end{tabular}


Table 5 Robustness of Model of OECD-LAC Remittance Flow Determinants ${ }^{\mathrm{a}}$

\begin{tabular}{|c|c|c|c|c|}
\hline Regressors & $\begin{array}{c}(1)^{\mathrm{a}} \\
\text { Panel OLS (RE) }\end{array}$ & $\begin{array}{c}(2)^{\mathrm{a}} \\
\text { Panel OLS (RE) }\end{array}$ & $\begin{array}{c}(3)^{\mathrm{a}} \\
\text { Panel OLS (RE) }\end{array}$ & $\begin{array}{c}(4)^{\mathrm{a}} \\
\text { Panel TSLS (RE) }\end{array}$ \\
\hline Host country GDP & $\begin{array}{c}0.78 * * \\
(4.67)\end{array}$ & $\begin{array}{c}0.84 * * \\
(6.17)\end{array}$ & $\begin{array}{c}0.73 * * \\
(7.14)\end{array}$ & $\begin{array}{c}0.76^{* *} \\
(7.92)\end{array}$ \\
\hline Home country GDP & $\begin{array}{c}1.18 * * \\
(9.19)\end{array}$ & $\begin{array}{c}1.17 * * \\
(7.81)\end{array}$ & $\begin{array}{c}0.94 * * \\
(8.65)\end{array}$ & $\begin{array}{c}0.89 * * \\
(7.88)\end{array}$ \\
\hline Distance & $\begin{array}{l}-2.02 * * \\
(-3.48)\end{array}$ & $\begin{array}{c}-1.33 * * \\
(-3.06)\end{array}$ & $\begin{array}{c}-1.62 * * \\
(-4.35)\end{array}$ & $\begin{array}{l}-1.68 * * \\
(-5.05)\end{array}$ \\
\hline GDP per capita differential & $\begin{array}{c}1.53 * * \\
(4.83)\end{array}$ & $\begin{array}{c}1.38 * * \\
(4.30)\end{array}$ & $\begin{array}{c}1.03 * * \\
(3.81)\end{array}$ & $\begin{array}{l}0.85 * * \\
(2.35)\end{array}$ \\
\hline Adjacency & $\begin{array}{c}1.80 * * \\
(3.89)\end{array}$ & - & $\begin{array}{l}1.92 * * \\
(4.77)\end{array}$ & $\begin{array}{l}1.58^{*} \\
(1.70)\end{array}$ \\
\hline Language & $\begin{array}{c}2.58 * * \\
(4.62)\end{array}$ & $\begin{array}{c}2.79 * * \\
(4.72)\end{array}$ & $\begin{array}{c}2.09 * * \\
(3.92)\end{array}$ & $\begin{array}{l}2.53 * * \\
(8.08)\end{array}$ \\
\hline Colony & $\begin{array}{l}-0.20 \\
(-0.28)\end{array}$ & $\begin{array}{l}-0.34 \\
(-0.49)\end{array}$ & $\begin{array}{l}0.74 \\
(1.22)\end{array}$ & \\
\hline Real interest rate differential & $\begin{array}{l}0.08 \\
(1.62)\end{array}$ & $\begin{array}{l}0.10^{*} \\
(1.86)\end{array}$ & $\begin{array}{c}-0.77 \times 10^{-2} \\
(-0.14)\end{array}$ & \\
\hline $\begin{array}{l}\text { Host country } \\
\text { real exchange rate }\end{array}$ & $\begin{array}{l}-0.36 \\
(-1.56)\end{array}$ & $\begin{array}{l}-0.15 \\
(-0.97)\end{array}$ & $\begin{array}{l}-0.02 \\
(-0.25)\end{array}$ & $\begin{array}{c}-0.04 \\
(-0.52)\end{array}$ \\
\hline $\begin{array}{l}\text { Home country } \\
\text { real exchange rate }\end{array}$ & $\begin{array}{l}0.09 * \\
(1.74)\end{array}$ & $\begin{array}{c}0.09 \\
(1.62)\end{array}$ & $\begin{array}{c}0.06 \\
(1.32)\end{array}$ & $\begin{array}{c}0.02 \\
(0.58)\end{array}$ \\
\hline $\begin{array}{l}\text { Host country } \\
\text { private sector credit }\end{array}$ & $\begin{array}{c}-0.45 * * \\
(-3.04)\end{array}$ & $\begin{array}{c}-0.45 * * \\
(-2.68)\end{array}$ & $\begin{array}{l}-0.03 \\
(-0.14)\end{array}$ & $\begin{array}{c}0.06 \\
(0.11)\end{array}$ \\
\hline $\begin{array}{l}\text { Home country } \\
\text { private sector credit }\end{array}$ & $\begin{array}{c}0.51 * * \\
(2.54)\end{array}$ & $\begin{array}{c}0.50 * * \\
(2.31)\end{array}$ & $\begin{array}{c}0.21 \\
(0.78)\end{array}$ & $\begin{array}{c}-0.31 \\
(-1.46)\end{array}$ \\
\hline Skills differential & $\begin{array}{c}1.35 * * \\
(3.65)\end{array}$ & $\begin{array}{c}1.30 * * \\
(3.21)\end{array}$ & $\begin{array}{c}0.82 * * \\
(2.93)\end{array}$ & $\begin{array}{l}1.80 * * \\
(4.90)\end{array}$ \\
\hline Dependency ratio differential & $\begin{array}{c}0.16^{* *} \\
(4.41)\end{array}$ & $\begin{array}{c}0.16^{* * *} \\
(4.81)\end{array}$ & $\begin{array}{c}0.09 * * \\
(2.82)\end{array}$ & $\begin{array}{c}0.22 * * \\
6.45\end{array}$ \\
\hline $\begin{array}{l}\text { Dependency ratio differential } \\
\times \text { Skills differential }\end{array}$ & $\begin{array}{c}-0.06 * * \\
(-3.28) \\
\end{array}$ & $\begin{array}{c}-0.06 * * \\
(-3.13) \\
\end{array}$ & $\begin{array}{l}-0.03 \\
(-1.13) \\
\end{array}$ & $\begin{array}{l}-0.12 * * \\
(-5.14)\end{array}$ \\
\hline
\end{tabular}


Table 5 cont'd

\begin{tabular}{|c|c|c|c|c|}
\hline Regressors & $\begin{array}{c}(1)^{\mathrm{a}} \\
\text { Panel OLS (RE) } \\
\end{array}$ & $\begin{array}{c}(2)^{\mathrm{a}} \\
\text { Panel OLS (RE) } \\
\end{array}$ & $\begin{array}{c}(3)^{\mathrm{a}} \\
\text { Panel OLS (RE) } \\
\end{array}$ & $\begin{array}{c}(4)^{\mathrm{a}} \\
\text { Panel TSLS (RE) } \\
\end{array}$ \\
\hline Natural disaster & $\begin{array}{c}0.28 * * \\
(2.29)\end{array}$ & $\begin{array}{c}0.29 * * \\
(2.41)\end{array}$ & $\begin{array}{c}0.18 * * \\
(2.32)\end{array}$ & $\begin{array}{l}0.18^{*} \\
(1.84)\end{array}$ \\
\hline Political risk & $\begin{array}{c}0.02 * * \\
(2.70)\end{array}$ & $\begin{array}{c}0.02 * * \\
(2.20)\end{array}$ & $\begin{array}{c}-0.49 \times 10^{-2} \\
(-0.57)\end{array}$ & $\begin{array}{l}-0.03 \\
(-1.43)\end{array}$ \\
\hline North America & $\begin{array}{l}-0.89 \\
(-1.21)\end{array}$ & - & - & \\
\hline Europe & $\begin{array}{l}-0.41 \\
(-0.83)\end{array}$ & - & - & \\
\hline Asia & $\begin{array}{l}1.28 \\
(0.82)\end{array}$ & - & - & \\
\hline Oceania & - & - & - & \\
\hline Intercept & $\begin{array}{c}-22.36 * * \\
(-2.34)\end{array}$ & $\begin{array}{c}-31.01 * * \\
(-3.72)\end{array}$ & $\begin{array}{c}-16.63 * * \\
(-2.38)\end{array}$ & $\begin{array}{c}-14.21 * * \\
(-2.79)\end{array}$ \\
\hline No. of obs & 353 & 318 & 343 & 405 \\
\hline Hausman $^{\text {b }}$ & & & & $\begin{array}{l}19.65 \\
(0.478)\end{array}$ \\
\hline No. of groups & 106 & 96 & 100 & 105 \\
\hline $\mathrm{R}^{2}$ & 0.750 & 0.700 & 0.785 & 0.810 \\
\hline LM test ${ }^{\mathrm{c}}$ & $168.02 * *$ & $207.09 * *$ & $276.84 * *$ & \\
\hline Anderson-Rubin Wald $\mathrm{F}$ test $\mathrm{d}^{\mathrm{d}}$ & & & & $\begin{array}{c}27.78 * * \\
(0.000)\end{array}$ \\
\hline Anderson canonical correlations test ${ }^{\mathrm{e}}$ & & & & $\begin{array}{c}110.22 * * \\
(0.000)\end{array}$ \\
\hline Sargan test ${ }^{\mathrm{f}}$ & & & & $\begin{array}{c}1.25 \\
(0.2634)\end{array}$ \\
\hline Time & $87.73 * *$ & $108.75 * *$ & $102.36 * *$ & $61.81 * *$ \\
\hline
\end{tabular}

${ }^{a}$ The reported test statistics in parentheses ( $z$ statistics for RE) are heteroskedasticity robust (White 1980). ${ }^{b}$ Test for the FE vs RE estimators (Hausman 1978). ${ }^{c} \mathrm{LM}$ test for random effects (Breusch and Pagan 1980). ${ }^{c}$ Test for instrument relevancy, it tests for the joint significance of all endogenous regressors. ${ }^{\mathrm{d}}$ Test for instrument relevancy, the null hypothesis is that the minimum canonical correlation is zero (low/non relevance). ${ }^{\mathrm{f}}$ Sargan test for over-identifying restrictions, the null hypothesis is that the instrument/s are exogenous. ${ }^{* *}$ denotes significance at the $5 \%$ level; * denotes significance at the $10 \%$ level. 
Figure 1 Workers Remittances and Compensation of Employees Received in the LAC Countries ${ }^{\mathrm{a}}$

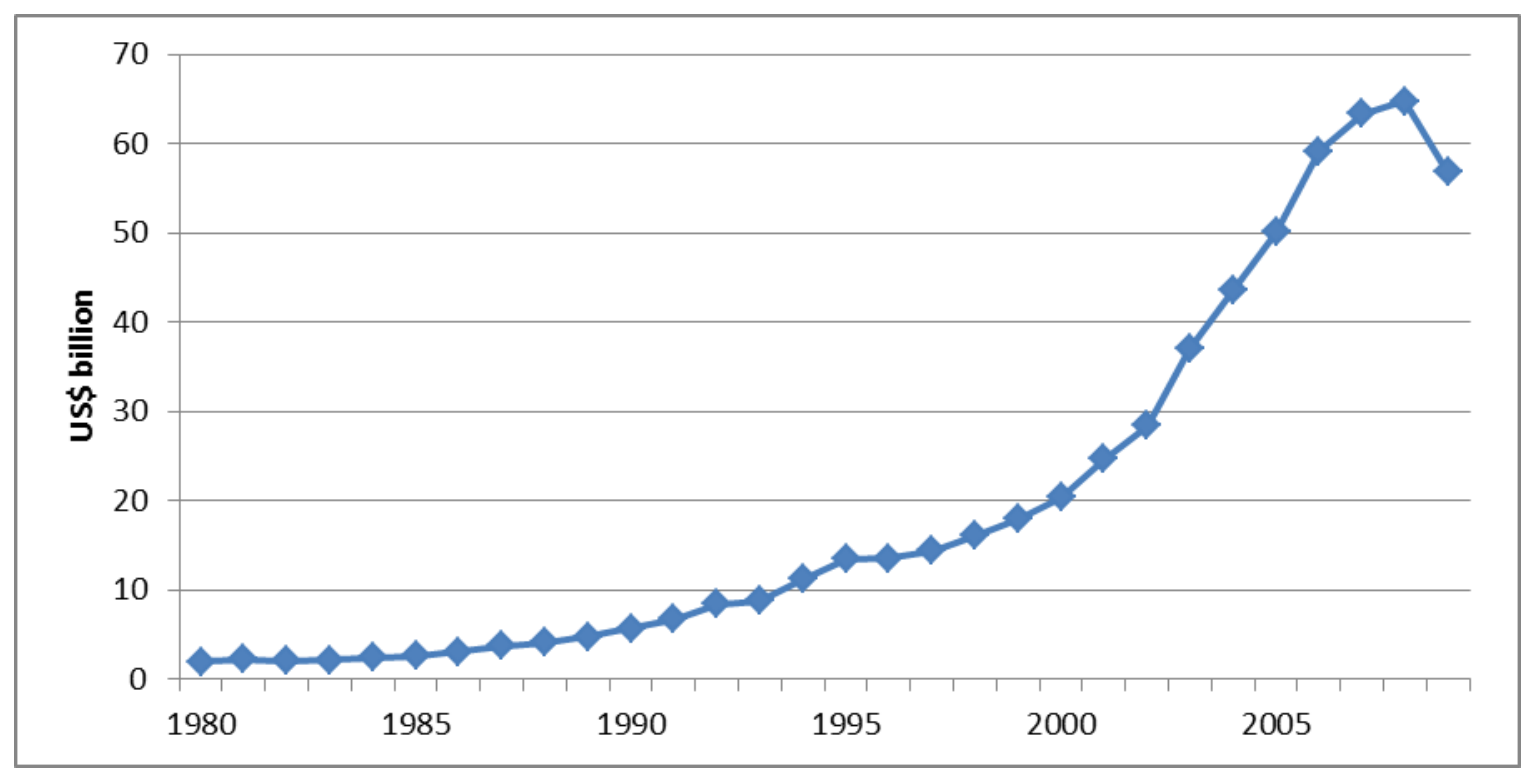

${ }^{a}$ Source: World Development Indicators, World Bank. 
Figure 2 Top-10 LAC Recipients of Remittances as at 2007 (US\$ billion) ${ }^{\mathrm{a}}$

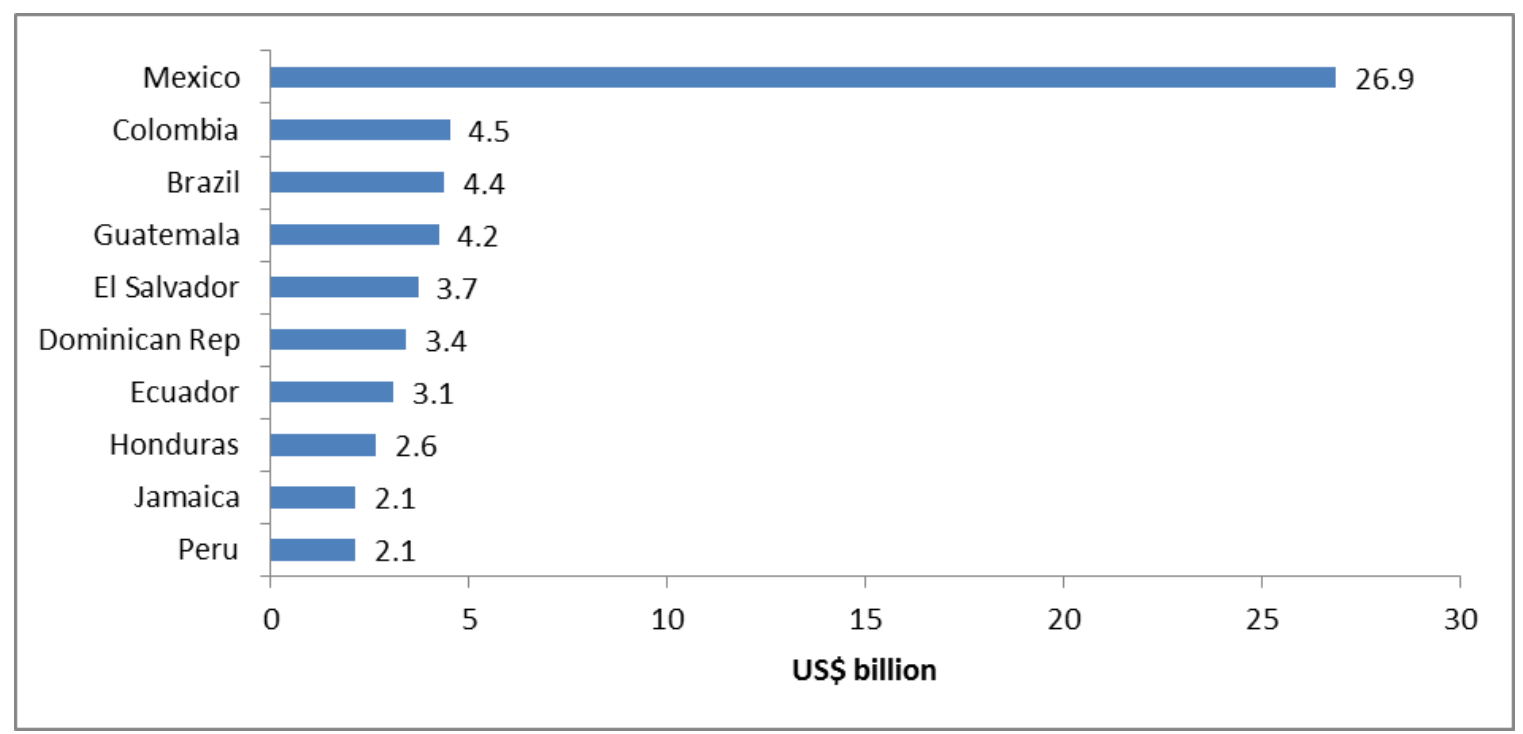

${ }^{a}$ Source: World Development Indicators, World Bank. 


\section{NOTES}

${ }^{1}$ Based on the authors' own calculations. Data is taken from World Development Indicators, http://data.un.org/DataMartInfo.aspx\#WDI. Data accessed 25/06/2015

${ }^{2}$ See http://www.worldbank.org/en/news/feature/2012/11/20/remesas-america-latina. Date accessed:07/05/2013

${ }^{3}$ Australia, Belgium, Canada, Denmark, France, Germany, Greece, Italy, Japan, Korea, the Netherlands, New Zealand, Norway, Portugal, Spain, Sweden, the United Kingdom, the United States.

${ }^{4}$ Argentina, Belize, Bolivia, Brazil, Chile, Colombia, Costa Rica, Dominica, Dominican Republic, Ecuador, El Salvador, Grenada, Guatemala, Guyana, Honduras, Haiti, Jamaica, Mexico, Nicaragua, Panama, Paraguay, Peru, St. Lucia, St. Vincent and the Grenadines, Suriname, Uruguay, Venezuela. ${ }^{5}$ Mathematically, $\gamma I^{i} \geq(I+\beta) \tau I^{j}$.

${ }^{6}$ It can be shown that as long as $\tau$ is small enough, the overall effect of an increase in $I^{j}$ or $\tau$ is negative. The condition (in conjunction with equation (1) is $\tau<\left[\left(R^{j}-R^{i}\right) /\left(p R^{j}-R^{i}\right)\right] \cdot[(1+\beta) / \beta]$ for which a sufficient condition is $\tau<[(1+\beta) / \beta]$ or simply $\tau<2$.

${ }^{7}$ It also depends on the cost of obtaining credit.

${ }^{8}$ A similar correlation is found for Jamaica.

${ }^{9}$ Models 3 and 4 are estimated and the fitted values obtained. These values are squared and cubed and subsequently added to the original model. The models without the fitted values are the restricted models and the ones with the fitted values are the unrestricted models. The joint significance of the fitted squared and cubed terms is then tested in the unrestricted models. The null hypothesis is that they are jointly equal to zero. Non-rejection of the null hypothesis indicates that the restricted models (without non-linear terms) are acceptable.

${ }^{10}$ The results for the components of natural disasters are available on request.

${ }^{11}$ The results for the components of political risk are available on request.

${ }^{12}$ The interest rate variable is dropped because the first stage F statistic is less than 10 . Since this variable was insignificant to begin with the removal is justified. All results are available upon request. 